ISSN 0258-7122 (Print), 2408-8293 (Online)

Bangladesh J. Agril. Res. 42(2): 321-341, June 2017

\title{
IMPORT AND EXPORT PARITY PRICE ANALYSES OF SELECTED VEGETABLES AND SPICES IN BANGLADESH
}

\author{
M. A. RASHID ${ }^{1}$, M. A. MONAYEM MIAH ${ }^{2}$ \\ AND TANVIR M. B. HOSSAIN ${ }^{2}$
}

\begin{abstract}
The study was undertaken to find out the export potentialities of selected vegetables and import substitution of selected spices in Bangladesh. Seven hundred twenty vegetables and 320 spices growers, 25 suppliers, and 25 exporters were randomly selected for the study.Net margin analysis was done on both variable and total cost basis. Domestic resource cost (DRC) analysis was also done for estimating comparative advantage of the selected vegetables and spices. The study revealed that net returns were positive for all vegetables and spices producers. However, the highest net return was estimated for brinjal producers (Tk. 273799/ha) followed by bittergourd producers (Tk152145/ha). In the case of spices, the highest net return was received by ginger producers (Tk. 231399/ha) followed by onion producers (Tk. 122308/ha).Comparatively lower net returns were found for okra (Tk51830/ha) and garlic producers (Tk 99352/ha). Vegetables exporters received the highest net margin (Tk32852/ ton) from UK market which was higher than the Middle East market (Tk22869/ton). The highest benefit cost ratio (BCR) was calculated for brinjal (1.9) followed by ash gourd (1.8). For spices, BCR were 2.1 and 1.8 for ginger and garlic respectively. Bangladesh had comparative advantage for producing all selected vegetables as the estimates of domestic resource cost (DRC) were less than one. The value of DRC for all selected spices were less than unity implied that the production of these spices would be highly efficient for import substitution. Therefore, the study have been undertaken to find out this issues.
\end{abstract}

Keywords: Import parity, export parity, domestic resource cost, benefit cost ratio.

\section{Introduction}

\subsection{Vegetables situation in Bangladesh}

Vegetable is one of the most essential food items for growth and maintenance the health of human beings. Bangladesh is pre-dominantly an agricultural country with rich soil and climatic condition. But it is the matter of regret that after four decades of independence, the country could not produce enough vegetables for the people. Bangladesh has potential for doubling or trebling its present production of vegetables to meet domestic demand and leave a substantial surplus for export. Currently, it can meet only $2-3 \%$ of the demand of vegetables in international markets. But this market share has all the possibilities of

${ }^{1}$ Principal Scientific Officer, ${ }^{2}$ Principal Scientific Officer, Agricultural Economics Division, Bangladesh Agricultural Research Institute (BARI), Gazipur-1701, Bangladesh. 
increasing fast provided proper plans are made and pursued effectively. This amount is, however, a pittance compared to the potential. Growing of vegetables for export can soon prove to be a highly rewarding activity provided supportive policies are adopted. Many educated unemployed persons are taking up vegetable growing as a form of self employment. This is, no doubt, helping to increase production. The quantity of export is not big, but sizeable enough to create market for the large ethnic population of the South Asian sub-continent residing in the UK and Gulf region. A large portion of all vegetables were exported and demand for Bangladeshi vegetables is increasing in the South Asian subcontinent and gulf region day by day. So the exporters could be able to earn more foreign exchange by exporting vegetables. The annual trend of vegetables export and their total value during 2000-2011 has been shown in Fig. 1. It was observed that the vegetables export from Bangladesh started declining from 2007 and continued up to 2009. After that period the export situation is fluctuating. This situation caused by many reasons, such as reduced outflow of migrant workers, higher air freight charge, and quality deterioration of vegetables.

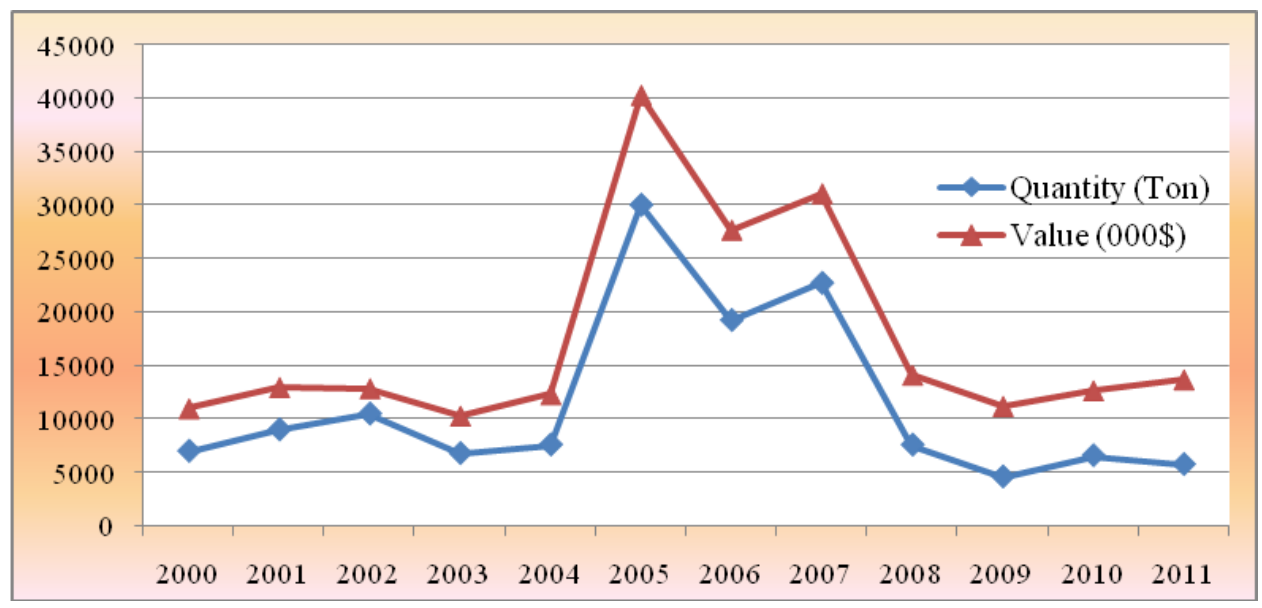

Fig. 1. Trend of vegetable exports in Bangladesh.

\subsection{Spices situation in Bangladesh}

Spices are popular as cash crops in Bangladesh. It has multipurpose uses. The major spices grown in the country are onion, garlic, chili, turmeric, and ginger. Onion, garlic and chili are short duration crops, whereas turmeric and ginger are long duration crops. Due to its higher demand the domestic production of spices cannot fulfill the country's demand. Therefore, a huge amount of spices has to importfrom foreign countries year after year. Different economic studies showed that the cost of production varied in a wide range among the spices produced in the country. In order to increase the domestic spices production, Bangladesh Government offers a lucrative credit facility on spice production at a lower interest rate. Unlike other agricultural crops, spices producers receive 
concessional credits at the rate of $2 \%$ annual interest since it is relatively most costly to produce. The trend of annual imports of spices and their values in Bangladesh during 2003-2011 have been shown in Fig. 2. It reveals that spices imports in Bangladesh started increasing from 2005 and continued up to 2009. After that period the quantity and value of imports reduced to a great extent due to the initiatives taken by the Government.

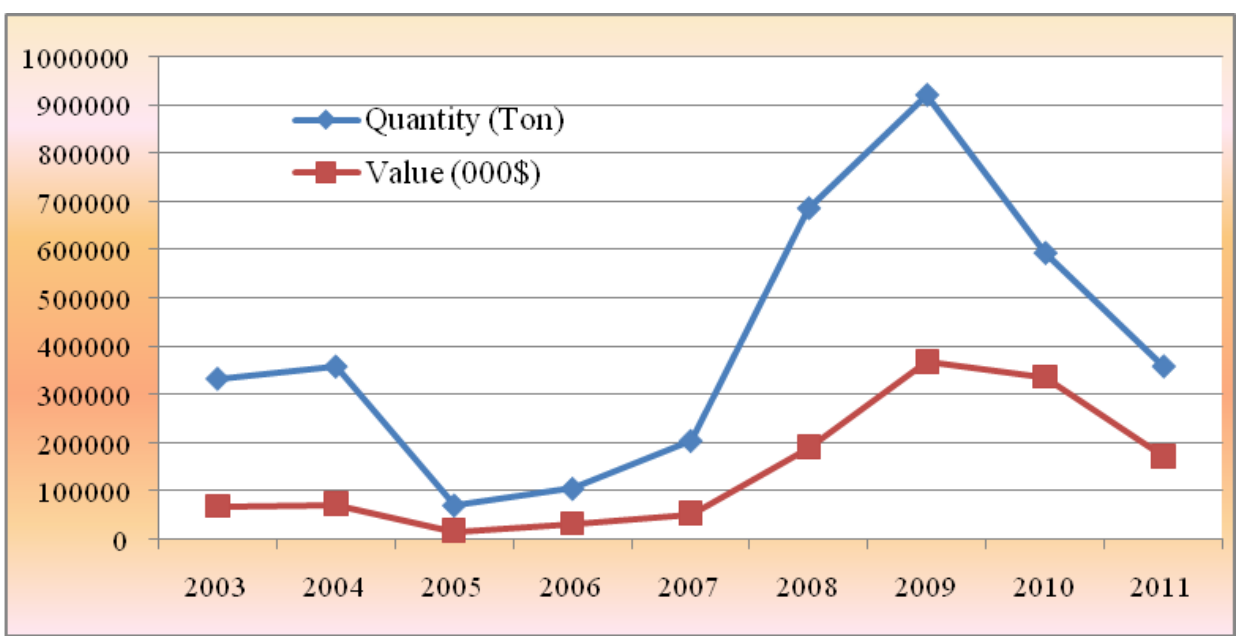

Fig. 2. Trend of spices import in Bangladesh.

\subsection{Export potentialities of vegetables and import substitution of spices in Bangladesh}

Export potentialities of vegetables and import substitution of spices would determine the position of the Bangladeshi cultivators in respect of production of commodities by using scarce resources. Farmers' perceptions of potentiality and constraints, public policies concerning irrigation, water control, technology and prices can influence their choice of crop growing. An evaluation of producing vegetables and spices relative to other crops for example, is required to address the issue of vegetables and spices self-sufficiency in the country both under the medium and long-term perspective. Again, the trading opportunities of the country's products depend on the comparative advantage, without subsidies or with limited subsidies that are permitted for all trading partners by the rules governing the new trading environment (Huda 2001). All these information would be of much help to the planners and policy-makers in formulating appropriate policies for optimum and efficient resource allocation within agriculture and between agriculture and non-agricultural sectors, consistent with a balanced and integrated development of Bangladesh economy. In order to formulate an appropriate policy for exporting vegetables and import substituting spices. Therefore, the present study was undertaken to highlight the economic performance of vegetables and spices. 


\subsection{Objectives}

i) To find out the export potentialities of selected vegetables in different locations;

ii) To estimate the import substitution status of the selected spices crops and

iii) To examine the policy implications from the above.

\section{Materials and Method}

\subsection{Selection of Sample Farmers}

The vegetables and spices growing farmers, suppliers, and exporters were considered as the population for this study. Keeping in view the objectives and time constraint of the study, altogether 720 vegetables taking 40 from each vegetable and each location, and 320 spices growers taking 40 from each location, 25 suppliers, and 25 exporters were randomly selected for the present study. The study areas were purposively selected based on intensive vegetables and spices growing pockets in Bangladesh. The distribution of crops and their respective locations and sample size are shown in Table 2.1.

Table 2.1 Crops and locations wise sample size of selected vegetables and spices

\begin{tabular}{ll|c}
\hline \multicolumn{1}{c|}{ Name of the crops } & \multicolumn{1}{c}{ Study location } & Sample size \\
\hline $\begin{array}{l}\text { Vegetables } \\
\text { Bitter gourd }\end{array}$ & Jessore and Narshingdi & 80 \\
Pointed gourd & Rangpur and Narshingdi & 80 \\
Ash gourd & Comilla and Narshigdi & 80 \\
Cucumber & Comilla and Narshigdi & 80 \\
Brinjal & Jessore and Narshingdi & 80 \\
Potato & Rangpur and Munshigonj & 80 \\
Country bean & Jessore and Narshingdi & 80 \\
Okra & Comilla and Narshingdi & 80 \\
Pumpkin & Barisal and Mymensingh & 80 \\
Spices & & \\
Onion & Rajshahi and Faridpur & 80 \\
Garlic & Natore and Nilphamari & 80 \\
Ginger & Natore and Nilphamari & 80 \\
Green chilli & Magura and Pabna & 80 \\
Total & & 1040 \\
\hline
\end{tabular}

Based on the availability of data, easy road communication, and nearest to Airport, Ulokhola of Kaligonj Upazila of Gazipur district was selected for 
selecting vegetable traders. Again, on the basis of collection of exportable items and the presence of export oriented trading firms, Motijheel, Kakrail, Shantinagar, Khilgaon and Shambazar of Dhaka city were selected for the study.

\subsection{Analytical Technique}

In this study, value addition or costs and returns analyses were done on both variable and total cost basis. The following equation (П) was developed to assess the value addition of the vegetables and spices producers.

$\Pi_{\mathrm{i}}=\sum_{i=1}^{n} \mathrm{P}_{\mathrm{i}} \mathrm{Q}_{\mathrm{i}}-\mathrm{TC}=\sum_{i=1}^{n} \mathrm{P}_{\mathrm{i}} \mathrm{Q}_{\mathrm{i}}-(\mathrm{VC}+\mathrm{FC})$

Where,

$$
\begin{aligned}
& \prod_{i}=\text { Profit or value addition from } \mathrm{i}^{\text {th }} \text { vegetables and spices production } \\
& \mathrm{Q}_{\mathrm{i}}=\text { Quantity of the } \mathrm{i}^{\text {th }} \text { product }(\mathrm{kg} / \mathrm{ha}) \\
& \mathrm{P}_{\mathrm{i}}=\text { Average price of } \mathrm{i}^{\text {th }} \text { product }(\mathrm{Tk} / \mathrm{kg}) \\
& \mathrm{TC}=\text { Total cost }(\mathrm{Tk} / \mathrm{ha}) \\
& \mathrm{VC}=\text { Variable cost }(\mathrm{Tk} / \mathrm{ha}) \\
& \mathrm{FC}=\text { Fixed cost }(\mathrm{Tk} / \mathrm{ha}) \\
& \mathrm{i}=1,2,3, \ldots \ldots \ldots . ., \mathrm{n}
\end{aligned}
$$

Per hectare profitability of growing vegetables and spices from the view points of individual farmers was measured in terms of gross return, gross margin and value addition.

Gross return: Gross return was calculated by simply multiplying the total volume of output with it's per unit of price in the harvesting period.

Gross margin: Gross margin calculation was done to have an estimate of the difference between total return and variable costs. The argument for using the gross margin analysis is that the farmers of Bangladesh are more interested to know their return over variable costs.

Net margin: The analysis considered fixed cost (which included lend rent, cost of equipment). Net margin was calculated by deducting all costs (Variable and Fixed) from gross return. Net margin of supplier and exporter is:-

Net margin $=$ Gross margin - Marketing cost

Gross margin $=$ Sale price - Purchase price

\subsection{Export and Import Parity Analysis}

The estimates of world price at import parity level are based on the assumption that imports compete with domestic production at the producer level. In case of exportable commodity, domestic-to-border price comparison has been made at 
producer level. The border prices of selected commodities have been adjusted for marketing cost (which includes handling, transportation, storage cost) and price spent between the wholesale market to the farmers level. Border prices of commodities are used as reference or shadow prices in measuring the effects of government intervention polices. Without government intervention, the domestic producer prices are expected to be closely related to the border prices.

Export parity:The export parity price at farm gate is estimated by using the following formulae:

$$
\mathrm{P}_{\mathrm{i}}=\mathrm{P}_{\mathrm{i}}^{\mathrm{b}} \mathrm{E}_{0}-\mathrm{C}_{\mathrm{i}}
$$

Where,

$\mathrm{P}_{\mathrm{i}}=$ Producer price of $\mathrm{i}^{\text {th }}$ exportable,

$\mathrm{P}_{\mathrm{i}}^{\mathrm{b}}=$ World price at the port of entry (f.o.b) in foreign currency

$\mathrm{E}_{0}=$ Exchange rate

$\mathrm{C}_{\mathrm{i}}=$ All components of the marketing margin from border to farm gate level

Import parity: Import parity price at farm level is estimated using the following formulae

$$
\mathrm{P}_{\mathrm{j}}=\mathrm{P}_{\mathrm{j}}^{\mathrm{b}}+\mathrm{C}_{\mathrm{jm}}-\mathrm{C}_{\mathrm{j}}
$$

Where,

$\mathrm{P}_{\mathrm{j}}=$ producer price of $\mathrm{j}^{\text {th }}$ importable commodity,

$\mathrm{P}_{\mathrm{j}}^{\mathrm{b}}=$ world price at port of entry (c.i.f),

$\mathrm{C}_{\mathrm{jm}}=$ marketing margin from the port of entry to the wholesale market and

$\mathrm{C}_{\mathrm{jd}}=$ Components of the marketing spread between the wholesale market and farm gate.

\subsection{Measures of Comparative Advantage}

Comparative advantage or efficiency of producing different crops in Bangladesh agriculture is analyzed here using Domestic Resource Cost (DRC) analysis. This indicator is formally defined as follows:

Domestic resource cost $(\mathrm{DRC})$ : The DRC is the ratio of the cost in domestic resources and non-traded inputs (valued at their shadow prices) of producing the commodity domestically to the net foreign exchange earned or saved by producing the good domestically.

Formally DRCs is defined as:

$\mathrm{DRC}=\frac{\text { Cost of domestic resource and non }- \text { traded inputsfor producing per unit of output }}{\text { Value of tradable output }- \text { Value of tradable inputs }}$ 


$$
D R C=\frac{\sum f_{i j} P_{j}^{d}}{U_{i}-\sum a_{j k} P_{k}^{b}}
$$

Where,

$f_{i j}=$ Domestic resource and non-traded inputs $j$ used for producing per unit commodity i

$\mathrm{P}_{\mathrm{j}}^{\mathrm{d}}=$ Price of non-traded intermediate inputs and domestic resource

$\mathrm{U}_{\mathrm{i}}=$ Border price of output $\mathrm{i}$

$a_{i k}=$ Amount of traded intermediate inputs for unit production of $i$

$\mathrm{P}_{\mathrm{k}}^{\mathrm{b}}=$ Border price of traded intermediate input

If DRC $<1$, the economy saves foreign exchange by producing the good domestically either for export or for imports substitution. This is because the opportunity cost of domestic resources and non-traded factors used in producing the good is less than the foreign exchange earned or saved. In contrast, if DRC > 1, domestic costs are in excess of foreign exchange costs or savings, indicating that the good should not be produced domestically and should be imported instead.

\section{Results and Discussion}

\subsection{Cost of Production of Different Vegetables}

Variable Cost:The cost of production included all kinds of variable costs such as human labour, mechanical power, seed/seedling, manure, fertilizers, irrigation, pesticides, etc. used for the production of selected vegetables. Both cash expenses and imputed value of family supplied inputs were included in the variable cost. The total variable cost of selected vegetables was Tk.168527 per hectare which was $82 \%$ of total cost of production. Higher variable cost was recorded with the brinjalfarmers (Tk.217885/ha) than that of other vegetables due to higher level of input used by the brinjal farmers and lower variable cost was recorded with the pumpkin farmers. Among the different cost items, human labourwas the major cost item which accounted for about $45 \%$ of total variable cost and $37 \%$ of total cost. The second highest cost item was support (Macha/bamboo) cost which accounted for about $29 \%$ of total variable cost and $24 \%$ of total cost. Fertilizer and irrigation cost shared about $11 \%$ and $4 \%$ of total cost and ranked third and fourth cost item, respectively. There was no wide variation of different locations of the farms in the cost of selected vegetables cultivation. The uses of some inputs such as Urea, TSP and MoP were found very minimum in the study areas (Table 3.1).

Fixed Cost: Rental value of land was considered as fixed cost of production. The cost of this item was Tk.37193 per hectare which was accounted for about $18 \%$ of total cost of production (Table 3.1). Rental value of land was found highestincountry bean cultivation (Tk.74800/ha) andbrinjal cultivation (Tk. 61393/ha) due more crop duration. 


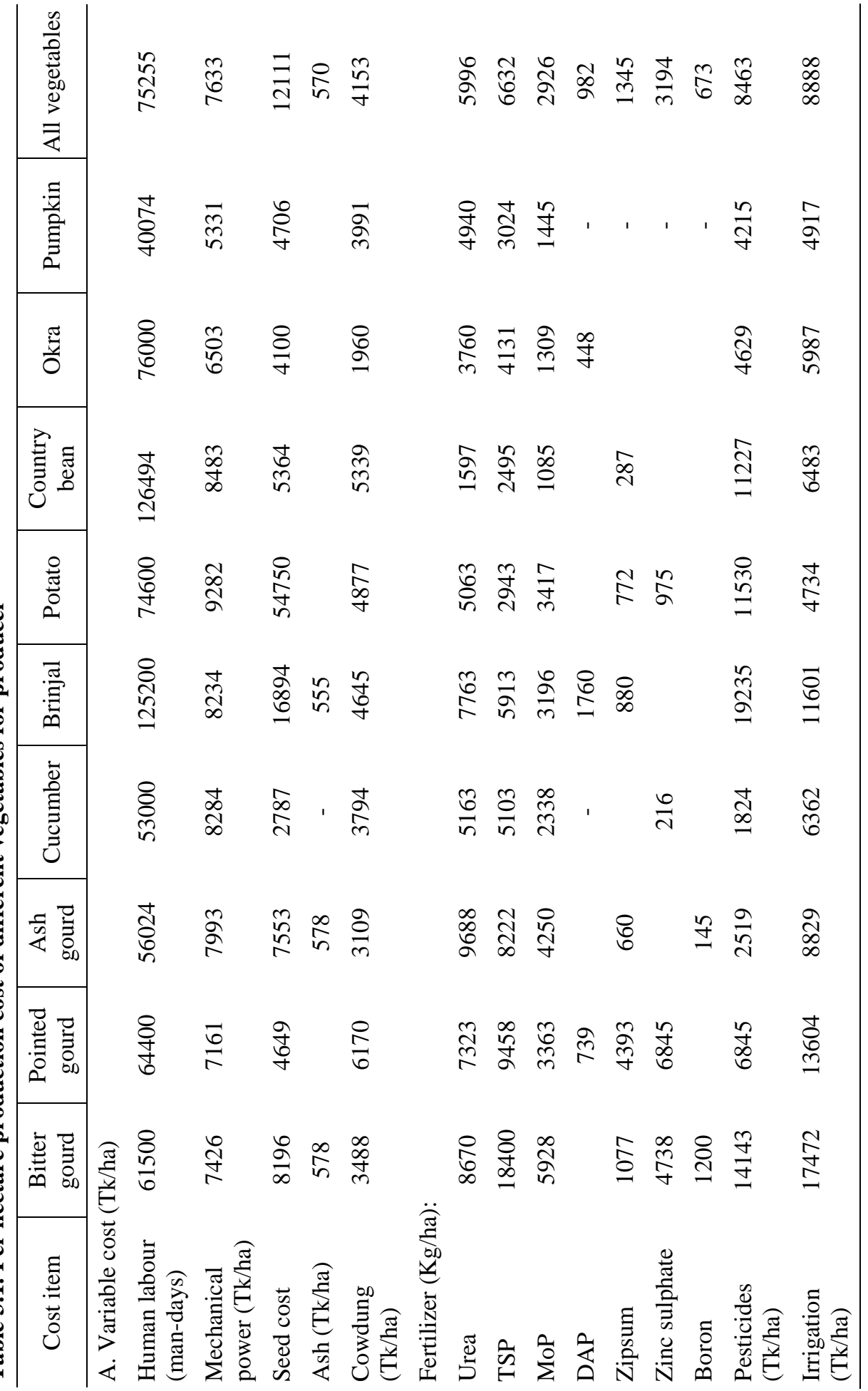




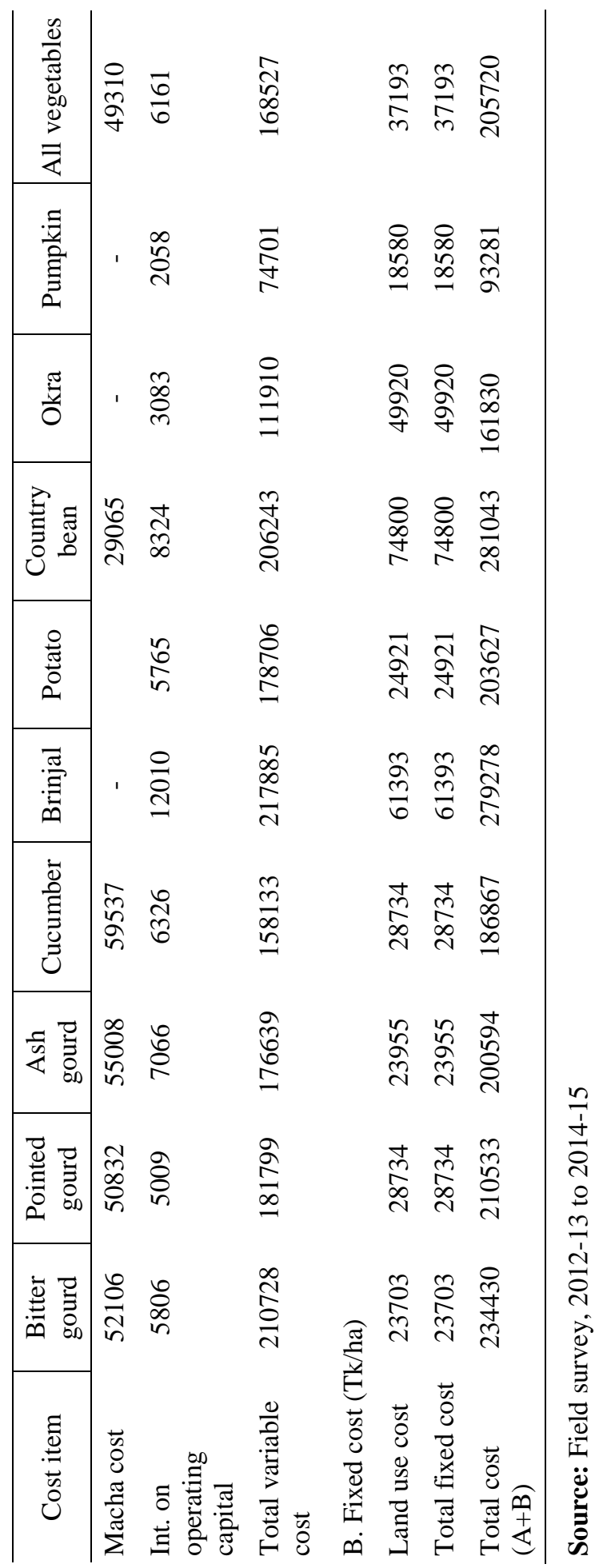


Total Cost: Total cost of production included variable costs and fixed costs incurred for selected vegetables cultivation. On an average, the total cost of production for selected vegetables cultivation was Tk.205720 per hectare where $18 \%$ were fixed costs and $82 \%$ were variable cost (Table 3.1). The highest total cost of production was incurred for country bean (Tk.281043/ha) followed by brinjal(Tk.279278/ha) and the lowest total cost of production was for pumpkin cultivation (Tk. 93281/ha).

\subsection{Cost of Production of Different Spices}

Variable cost: The averagetotal variable cost of spices cultivation was Tk.139840 per hectare which was $83 \%$ of total cost of production. Thehighest variable cost was recorded with the farmers of ginger (Tk. 173110/ha) than that of other spices due to use higher level of inputs. Among different cost items, human labour was the major cost item which accounted for about $40 \%$ of total variable cost and 33\% of total cost (Table 3.2). The second highest cost item was seed which accounted for about $25 \%$ of total variable cost and $21 \%$ of total cost. Fertilizerand irrigation cost accounted for about $13 \%$ and 5\% of total cost and ranked third and fourth cost item, respectively. The uses of some inputs such as Urea, TSP and MoP were found very minimum in the study areas for producing selected spices.

Table 3.2. Per hectare production cost of different spices for producer

\begin{tabular}{lccccc}
\hline Cost item & Onion & Garlic & Ginger & Chilli & All spices \\
\hline A. Variable cost (Tk/ha) & & & & & \\
Human labour & 57200 & 52600 & 51600 & 62600 & 56000 \\
Mechanical power & 6737 & 5838 & 9731 & 9402 & 7927 \\
Seed cost & 38959 & 9772 & 90388 & 2700 & 35455 \\
Ash & 555 & & & & 555 \\
Cowdung & 5039 & 4877 & & 6506 & 5474 \\
Fertilizer & & & & & \\
$\quad$ Urea & 6630 & 3060 & 3888 & 5900 & 4870 \\
$\quad$ TSP & 5188 & 5125 & 3767 & 5265 & 4836 \\
$\quad$ MoP & 4384 & 3216 & 2678 & 3179 & 3364 \\
$\quad$ DAP & 4995 & & & 4288 & 4642 \\
$\quad$ Zipsum & 552 & 804 & 132 & 560 & 512 \\
$\quad$ Zinc sulphate & 1005 & 938 & 244 & 1200 & 847 \\
$\quad$ Boron & 1350 & 3600 & & 1160 & 2037 \\
Pesticides & 11916 & 2882 & 520 & 3909 & 4807 \\
Irrigation & 17941 & 4749 & 3105 & 8981 & 8694 \\
Machha cost & - & & & - & \\
Int. on operating capital & 4688 & 2761 & 7057 & 3277 & 4446 \\
Total variable cost & 167137 & 100221 & 173110 & 118927 & 139849 \\
(Tk/ha) & & & & & \\
B. Fixed cost (Tk/ha) & & & & & \\
Land use cost & 26393 & 31851 & 37303 & 17465 & 28253 \\
Total fixed cost (Tk/ha) & 26393 & 31851 & 37303 & 17465 & 28253 \\
Total cost (A+B) & 193529 & 132072 & 210413 & 136392 & 168102 \\
\hline
\end{tabular}

Source: Field survey, 2012-13 to 2014-15. 


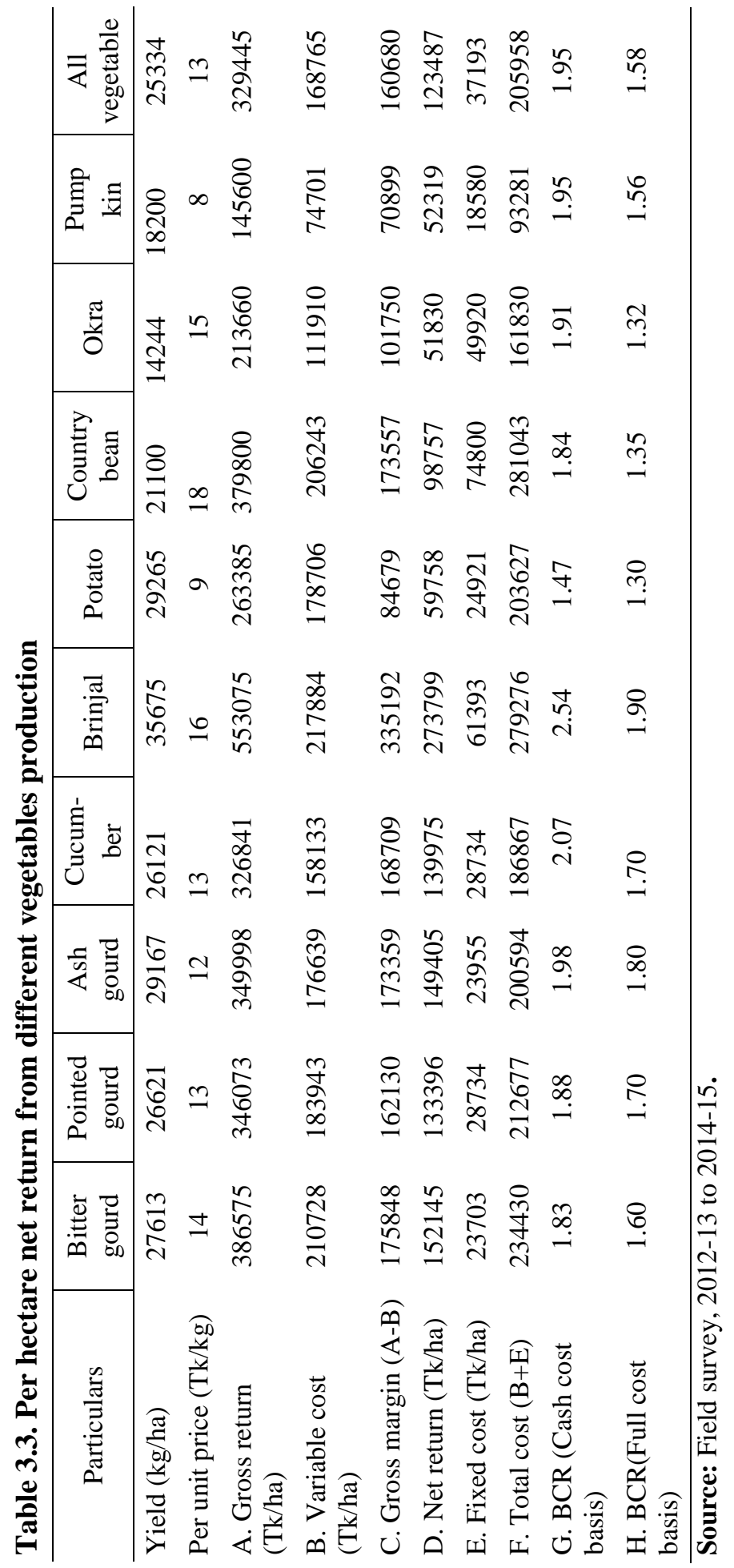


Fixed cost: The average rental value of land of selected spices was Tk. 28253 per hectare which incurred $17 \%$ of the total cost of production (Table 3.2). Rental value of land was found highestinginger cultivation (Tk. 37303/ha) compared to other selected spices cultivation.

Total cost: On an average, the total cost of production of selected spices was Tk.168102 per hectare, where 17\% was fixed costs and 83\% was variable cost (Table 3.2). The highest total cost of production was incurred for ginger (Tk.210413/ha) followed by onion (Tk.193529/ha).

\subsection{Net Returns of Different Vegetables Cultivation}

The average gross return of different vegetables was estimated at Tk.329445/ha (Table 3.3). Thehighest gross return was obtained from brinjal cultivation (Tk.553075/ha) compared to bitter gourd cultivation (Tk. 386575/ha). The highest gross return from brinjalcultivation was attributed to the highest yield and higher market price. Average gross margin was Tk.160680 per hectare which varied from Tk.335192/ha to Tk.70899/ha. Net return was also followed similar trend. It was evident that the average net returnofselected vegetables production wasestimated at Tk.123487 per hectare which was very high compared to other vegetables. As the production cost was also very high, the resource poor farmers could not afford such high cost. The average benefit cost ratio (BCR) was 1.6 on full cost basis, the highest being with the brinjal growers (1.9). Although the brinjal growers obtained the highest gross margin, BCR was also highest compared to others vegetable.

Table 3.4. Per hectare net return from different spices production

\begin{tabular}{lcccccc}
\hline Particulars & Onion & Garlic & Ginger & Chilli & All \\
\hline Yield (kg/ha) & 17547 & 6172 & 8350 & 7180 & 9812 \\
Per unit price (Tk/kg) & 18 & 38 & 52 & 33 & 35 \\
A. Gross return (Tk/ha) & 315837 & 231424 & 429973 & 236940 & 303544 \\
B. Variable cost (Tk/ha) & 167137 & 100221 & 181271 & 118927 & 141889 \\
C. Gross margin (A-B) & 148701 & 131203 & 248702 & 118013 & 161655 \\
D. Net return (Tk/ha) & 122308 & 99352 & 231399 & 100548 & 138402 \\
E. Fixed cost (Tk/ha) & 26393 & 31851 & 17303 & 17465 & 23253 \\
F. Total cost (B+E) & 193529 & 132072 & 198574 & 136392 & 165142 \\
G.BCR (Cash cost basis) & 1.89 & 2.31 & 2.37 & 1.99 & 2.14 \\
H. BCR(Full cost basis) & 1.60 & 1.80 & 2.10 & 1.73 & 1.81 \\
\hline
\end{tabular}

Source: Field survey, 2012-13 to 2014-15

\subsection{Net Returns of Different Spices Production}

The average gross return from selected spicesproduction was estimated at Tk.303544 per hectare (Table 3.4). The highest gross return was obtained by the 
ginger growers (Tk.429973/ha) than that of onion growers (Tk.315837/ha). The highest gross return from gingerproduction was attributed tothe highest yield and higher market price. Average gross margin was found to be Tk.161655 per hectare which varied from Tk. 248702/ha to Tk. 118013/ha. Similar trend was found in calculating net returns. The average net return from selected spicesproduction was Tk.138402 per hectare. The average benefit cost ratio (BCR) was 1.81 on full cost basis.

\subsection{Marketing Cost and Margin of Vegetables Supplier}

A supplier was the part time or full time agent of the different exporters in the production area. Therefore, marketing cost was only calculated for supplier in the study areas. The marketing costs of selected vegetables are shown in Table 3.5. The estimated average marketing costs per ton of vegetables incurred by suppliers were Tk. 3730.

Table 3.5. Marketing cost of vegetables incurred by supplier

\begin{tabular}{lcc}
\hline Cost item & Cost (Tk/ton) & Percent of total cost \\
\hline Transportation & 2000 & 53.62 \\
Loading and unloading & 400 & 10.72 \\
Grading & 250 & 6.70 \\
Wastage/loss of weight & 425 & 11.39 \\
Market toll & 275 & 7.37 \\
Tips and donation & 100 & 2.68 \\
House rent & 80 & 2.14 \\
Personal expenses & 200 & 5.36 \\
Total & 3730 & 100 \\
\hline
\end{tabular}

Field survey, 2014

The net margin of supplier is shown in the Table 3.6. The average purchase price of suppliers was Tk. 13,111 per ton and the average sale price was Tk. 19,333 per ton. Thus the gross margin of suppliers was Tk. 6,111 per ton. The total marketing cost of suppliers was Tk. 3730 per ton. So, the net margin of suppliers was Tk. 2381 per ton of vegetables.

\subsection{Marketing Cost and Margin of Vegetables Exporters}

Of the total costs, the highest cost was incurred by the airfreight charge followed by packet/carton, terminal and handling charge, carrying from exporters go-down to airport, clearing and forwarding. The per unit cost of many items were fixed irrespective of importing countries. The exporters incurred higher cost for exporting vegetables to UK followed by Middle East (Table 3.7). 
Table 3.7. Marketing cost (Tk/ton)of exporters for different vegetables export

\begin{tabular}{lcc}
\hline Cost items & United kingdom & Middle East \\
\hline Packet/Carton & 4000 & 4000 \\
Packaging materials e.g. rope, cost tape, thin paper etc. & 350 & 300 \\
Carrying from exporters godown to airport & 1500 & 1500 \\
Clearing and forwarding (C\&F) & 1500 & 1500 \\
Terminal and handling charge (THC) & 3450 & 3450 \\
Bank services & 70 & 70 \\
Airway bill charge & 552 & 216 \\
GSP certificate charge & 350 & - \\
Airfreight charge & 153000 & 101000 \\
EXP (Export perform) & 300 & 300 \\
Salary and wages & 1000 & 1000 \\
Office, godown rent and taxes & 1400 & 1200 \\
Telephone, fax, telex & 800 & 500 \\
Loading and unloading charge & 300 & 300 \\
Quarantine & 500 & 500 \\
Phyto-sanitary certificate & 200 & - \\
Metropolitan chamber of commerce office charge & 500 & 500 \\
Dhaka chamber of commerce office charge & 1500 & 1500 \\
Commission agent & 500 & 500 \\
Entertainment & 120 & 90 \\
Miscellaneous & 70 & 50 \\
Total cost & 171962 & 118476 \\
\hline
\end{tabular}

Source: Vegetable exporters and different airlines from airport 2014.

Net margin by exporters consisted of the profit from the export of vegetables. Exporters performed the function of purchasing exportable vegetables from supplier/selected agents and supply them to different foreign buyers of the world. The average net margin of the exporters is depicted in Table 3.8. It is revealed that net marginwas very high in the UK market (Tk. 32852/ton) followed by Middle East (Tk. 22869/ton).

Table 3.8. Net margin (Tk/ton) of vegetables exporters

\begin{tabular}{lcc}
\hline Particulars & United Kingdom & Middle East \\
\hline A. Average selling price in abroad (Tk/ton) & 224147 & 160678 \\
B. Average purchase price (Tk/ton) & 19333 & 19333 \\
C. Gross margin (A-B) & 204814 & 141345 \\
D. Marketing cost (Tk/ton) & 171962 & 118476 \\
E. Net margin (C-D) & 32852 & 22869 \\
\hline
\end{tabular}

Source: Field survey, 2012-13 to 2014-15. 


\subsection{Comparative Advantages of Vegetables and Spices Production}

DRC indicates whether the domestic economy has a comparative advantage in vegetables and spices crops production relative to other countries. If the DRC is greater than one, it implies that the economy loses foreign exchange through domestic production of the vegetables and spices (in the sense that it uses more domestic resources than it generates net value added to tradable goods and services), while DRC is less than one implies that the production is efficient and make positive contribution to domestic value addition. The estimates of DRCs for selected vegetables and spices during the period from 2012-13 to 2014-15 are presented in Table $3.9 \&$ 3.10. The DRCs for selected vegetables and spices were observed to be less than unity implying that Bangladesh had comparative advantage in vegetables production for export promotion and spices production for import substitution. The study results supported in the earlier study by Rashid et al., 2010.

Table 3.10. Domestic resource cost (DRC) of selected spices

\begin{tabular}{lcc|c|c}
\hline \multirow{2}{*}{ Items } & Onion & Garlic & Ginger & Chilli \\
\cline { 2 - 5 } & Import Parity & Import Parity & Import Parity & Export parity \\
\hline A. Traded input (Tk/MT) & 2001 & 3099 & 1838 & 3190 \\
$\begin{array}{l}\text { B. Non-Traded inputs and } \\
\text { domestic resources }\end{array}$ & 9624 & 18686 & 22499 & 15994 \\
$\begin{array}{l}\text { (Tk/MT) } \\
\text { Human labour }\end{array}$ & 3260 & 8522 & 6180 & 8719 \\
Mechanical power & 384 & 946 & 1165 & 1309 \\
Seed & 2220 & 1583 & 10825 & 376 \\
$\quad$ Ash & - & - & - & - \\
$\quad$ Manure & 287 & 790 & - & 906 \\
$\quad$ Pesticides & 679 & 467 & 62 & 544 \\
Irrigation & 1022 & 769 & 372 & 1251 \\
$\quad$ Macha & & & - & - \\
Int. on operating & 267 & 447 & 1823 & 456 \\
capital & & & & \\
$\quad$ Land rent & 1504 & 5161 & 2072 & 2432 \\
C. Output price (Tk/MT) & 30694 & 125251 & 58849 & 57325 \\
D. Value added & 28693 & 122152 & 57011 & 54135 \\
(Tradable) (Tk/MT) (C-A) & & & & \\
E. DRC (B/D) & 0.335 & 0.200 & 0.395 & 0.295 \\
\hline
\end{tabular}

Source: Authors' calculation. 


\subsection{Supply Chains for Vegetables Export}

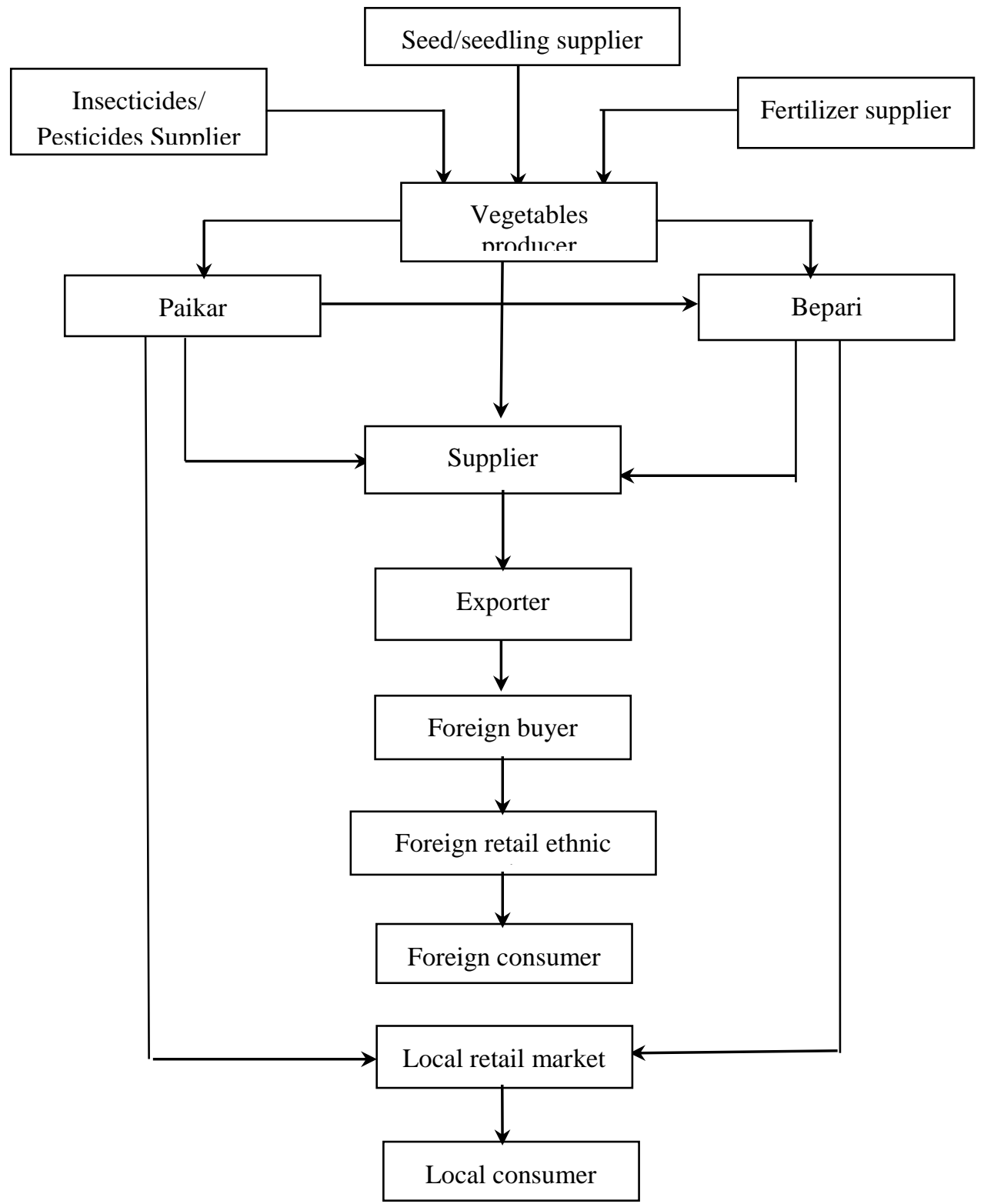

Fig. 2. Supply chains for vegetables export.

\section{Conclusions and Recommendations}

\subsection{Conclusions}

The study revealed that net margins were positive for all vegetables and spices producers. However, the highest net return was estimated for brinjal producers 
followed by bitter gourd producers. In the case of spices, the highest net return was received by ginger producers followed by onion producers. Comparatively low net returns were found for okra and garlic producers. Vegetables exporters received the highest net margin from UK market which was higher than the Middle East market.The highest benefit cost ratio (BCR) was calculated for brinjal followed by ash gourd. For spices, it the estimated BCR were 2.1 and 1.8 for ginger and garlic respectively. Bangladesh had comparative advantage of producing all selected vegetables and spices as the estimates of domestic resource cost (DRC) were less than one. This is a clear indication that although not yet a major supply source, Bangladesh seemed to have a high potential for export development of horticultural crops, particularly, in vegetables and spices. The country has got some natural advantages like fertile soil, favorable climatic condition, and abundant supply of inexpensive labour force. The export of fresh vegetables is more profitable due to high value addition. Raw materials are not to be imported for vegetables export. Bangladeshi vegetables are still not well known to the foreign consumers. Export expansion and demand from super market was constrained by poor quality of produces and imposition of different sanitary and phyto-sanitary criteria by the importing countries. To familiarize Bangladeshi vegetables to the foreigners and foreign super markets, quality of those vegetables has to be improved by upgrading the packaging, handling, gradingand transportation system. Therefore, quality assurance would be must and it required continuous market research for improving the demand of Bangladeshi fresh vegetables in the international markets.

\subsection{Recommendations}

Selected vegetables production could be expanded for export promotion by using more improved technology as the country's demand. So emphasis should also be given on local production of selected vegetables as the export parity is favorable for the country.

Domistic resource cost for all spices crops were also less than unity implying that production of these spices would be highly efficient for import substitution.

To survive and sustain in the export market in this context and to ensure and enhance market excess and export competitiveness, the combined efforts of the concerned parties are necessary at the level of policy formulation, planning and implementation of programs.

\section{References}

Huda, A. (2001), Analysis of Protection and Comparative Advantage of Selected Agricultural Commodities in Bangladesh. An unpublished MS Thesis. Department of Agricultural Economics, BAU, Mymensingh

Rashid, M. A.; Hasan, M. K. and Rashid, A. K. M. H. (2010).Domestic and international competiveness of production of selected crops in Bangladesh, Final report on the challenge fund project (CF\#1/08) of NFPCSP/FAO, Ministry of Food and Disaster Management, Dhaka. 
Appendix 1. Total export quantity of vegetables

\begin{tabular}{cccc}
\hline Year & Quantity (Ton) & Value $(000 \$)$ & Unit value (\$/Ton) \\
\hline 2000 & 7000 & 11000 & 1571 \\
2001 & 9000 & 13000 & 1444 \\
2002 & 10484 & 12888 & 1229 \\
2003 & 6779 & 10323 & 1523 \\
2004 & 7592 & 12333 & 1624 \\
2005 & 30070 & 40242 & 1338 \\
2006 & 19263 & 27672 & 1437 \\
2007 & 22744 & 31071 & 1366 \\
2008 & 7574 & 14132 & 1866 \\
2009 & 4589 & 11236 & 2453 \\
2010 & 6577 & 12689 & 1929 \\
2011 & 5753 & 13704 & 2382 \\
\hline
\end{tabular}

Source: www.faostat.org

Appendix 2. Total import quantity of onion, garlic and ginger

\begin{tabular}{c|c|c|c|c|c|c}
\hline \multirow{2}{*}{ Year } & \multicolumn{2}{|c|}{ Onion } & \multicolumn{2}{c|}{ Garlic } & \multicolumn{2}{c}{ Ginger } \\
\cline { 2 - 7 } & $\begin{array}{c}\text { Quantity } \\
\text { (Ton) }\end{array}$ & $\begin{array}{c}\text { Value } \\
(000 \$)\end{array}$ & $\begin{array}{c}\text { Quantity } \\
(\text { Ton })\end{array}$ & $\begin{array}{c}\text { Value } \\
(000 \$)\end{array}$ & $\begin{array}{c}\text { Quantity } \\
(\text { Ton })\end{array}$ & $\begin{array}{c}\text { Value } \\
(000 \$)\end{array}$ \\
\hline 2003 & 334521 & 69003 & -- & N/A & N/A & N/A \\
2004 & 359589 & 73732 & -- & N/A & N/A & N/A \\
2005 & 72391 & 17338 & N/A & N/A & N/A & N/A \\
2006 & 106975 & 32880 & N/A & N/A & N/A & N/A \\
2007 & 96446 & 30809 & 109443 & 22248 & N/A & N/A \\
2008 & 686756 & 190873 & N/A & N/A & N/A & N/A \\
2009 & 767548 & 262244 & 103884 & 70699 & 49496 & 35595 \\
2010 & 505886 & 207150 & 50898 & 86622 & 37585 & 43065 \\
2011 & 268109 & 89611 & 44072 & 44231 & 47939 & 38061 \\
\hline
\end{tabular}

Source: www.faostat.org

Appendix 3. Import parity border prices of spices 2012-13 to 2014-15

\begin{tabular}{lccc}
\hline Items & Onion & Garlic & Ginger \\
\hline A. CIF PRICE (US\$ /mt) & 409 & 1702 & 794 \\
B. CIF price (Tk/mt) & 29039 & 120842 & 56374 \\
$\begin{array}{lcc}\text { C. Marketing margin from the port of entry to } \\
\quad \text { wholesale market }\end{array}$ & 2039 & 4793 & 2859 \\
$\begin{array}{l}\text { Import handling cost } \\
\text { Transportation cost }\end{array}$ & 871 & 3625 & 1691 \\
$\begin{array}{l}\text { Domestic trading cost } \\
\text { D. Border price at Wholesale level (B+C) }\end{array}$ & 1016 & 1016 & 1016 \\
$\begin{array}{l}\text { E. Components of the marketing spread between the } \\
\quad \text { wholesale market to the produce level }\end{array}$ & 31078 & 125635 & 59233 \\
F. Border price of farm produce at farm gate (D-E) & 30694 & 384 & 384 \\
\hline
\end{tabular}

Source: Authors calculation. 
